DOI https://doi.org/10.30525/978-9934-26-007-0-9

\title{
ДОГОВОРИ У СФЕРІ ІНТЕЛЕКТУАЛЬНОӤ ВЛАСНОСТІ ЗА ЗАКОНОДАВСТВОМ УКРАЇНИ
}

\section{Дмитренко В. В.}

\section{ВСТУП}

Об'єкти права інтелектуальної власності відрізняються від об'єктів речового права, тому в Цивільному кодексі України від 16 січня 2003 р. (далі - ЦК України) виділено окремі види договорів щодо розпоряджання майновими правами інтелектуальної власності. Зокрема, про такі договори йдеться у гл. 75 «Розпоряджання майновими правами інтелектуальної власності» та гл. 76 «Комерційна концесія» ЦК України. Виділення окремих договорів для об'єктів права інтелектуальної власності зумовлено, зокрема, їхньою правовою природою як результатів творчої, інтелектуальної діяльності людини, нематеріальністю та потенційною можливістю одночасного використання різними суб'єктами. Нематеріальний характер об'єктів права інтелектуальної власності дозволяє їх одночасне використання необмеженою кількістю осіб. Договори, призначені для речового права, не застосовують із метою розпоряджання майновими права інтелектуальної власності. Договори у сфері інтелектуальної власності спрямовані на розпоряджання саме майновими правами інтелектуальної власності, а не об'єктами як речами. Коли особа, якій належать майнові права на результати інтелектуальної, творчої діяльності, вступає в договірні правовідносини щодо розпоряджання майновими правами інтелектуальної власності, вона може надати іншій особі дозвіл на використання об'єкта права інтелектуальної власності чи взагалі відчужити майнові права інтелектуальної власності на користь іншої особи. Також можуть виникати правовідносини щодо створення об’єктів права інтелектуальної власності на замовлення. Договори у сфері інтелектуальної власності досліджували В.О. Бажанов, В.С. Дмитришин, О.В. Жилінкова, І.Ф. Коваль, А.О. Кодинець, О.С. Яворська, I.С. Якубівський та інші, проте багато питань залишаються дискусійними та неврегульованими в законодавстві. Розглянемо особливості цих договорів, що відрізняють їх від інших цивільно-правових договорів, і охарактеризуємо окремі види договорів у сфері інтелектуальної власності, виділені в чинному законодавстві України, недоліки законодавчого регулювання та шляхи їх усунення.

\section{1. Особливості договорів у сфері інтелектуальної власності}

Предмет договору. Предметом договорів, які укладаються стосовно об’єктів права інтелектуальної власності, $є$ розпоряджання майновими правами інтелектуальної власності - надання дозволу на використання 
об'єктів права інтелектуальної власності, відчуження майнових прав інтелектуальної власності. Також договори у сфері інтелектуальної власності можуть укладатись щодо створення об'єктів права інтелектуальної власності на замовлення. Варто звернути увагу на те, що розпоряджання можливе лише майновими правами інтелектуальної власності. Особисті немайнові права інтелектуальної власності $є$ невідчужуваними та не можуть надаватись у використання. Назва гл. 75 ЦК України «Розпоряджання майновими правами інтелектуальної власності» частково відповідає положенням, що висвітлені в цій главі. По-перше, саме поняття «розпоряджання майновими правами інтелектуальної власності» $є$ широким і включає не тільки договірні способи розпоряджання, тоді як у гл. 75 ЦК України йдеться суто про договори у сфері інтелектуальної власності. У літературі ${ }^{1}$ до недоговірних способів розпоряджання майновими правами інтелектуальної власності відносять їх передання в порядку спадкування. По-друге, розпоряджатися можна майновими правами, які є на момент укладення договору. Тоді як на час укладення договору про створення на замовлення і використання об'єкта права інтелектуальної власності відповідний результат буде в майбутньому. Тож видається доцільним викласти назву гл. 75 ЦК України як «Договори у сфері інтелектуальної власності», додати до неї положення про договір комерційної концесії, оскільки виділений окремо в законодавстві України ${ }^{2}$ договір комерційної концесії теж спрямований на розпоряджання майновими правами інтелектуальної власності.

Об 'єкти права інтелектуальної власності, щуодо яких можливе укладання договорів щюдо розпоряджання майновими правами інтелектуальної власності. Не всі об'єкти права інтелектуальної власності можна створити, надати у використання чи відчужити за договором. Це стосується насамперед наукових відкриттів та географічних зазначень. Обмежене право розпоряджання майновими правами також щодо комерційних найменувань та комерційних таємниць. Крім того, не кожен об'єкт права інтелектуальної власності можна створити на замовлення, якщо, зокрема, для виникнення майнових прав інтелектуальної власності необхідна державна реєстрація.

Наукові відкриття не створюються людиною, а встановлюються, оскільки людина вперше заявляе про закономірності, властивості чи явища, які існували у природі, проте не були відомі раніше. Тому майнових прав на наукове відкриття не виникає, оскільки з моменту його встановлення об'єкт переходить у суспільне надбання, а особа, яка його відкрила, іменується

\footnotetext{
${ }^{1}$ Дмитришин В.С. Розпоряджання майновими правами інтелектуальної власності в Україні : навчальний посібник. Київ : Інститут інтелектуальної власності і права, 2008. С. 33.

${ }^{2}$ Цивільний кодекс України : Закон України від 16 січня 2003 р. № 435-IV. URL: http://zakon.rada.gov.ua/ laws/show/435-15 (дата звернення: 25.11.2020) ; Господарський кодекс України : Закон України від 16 січня 2003 p. № 436-IV. URL: https://zakon.rada.gov.ua/laws/show/436-15 (дата звернення: 25.11.2020).
} 
автором та має лише особисте немайнове право на встановлений об'єкт. Оскільки на наукові відкриття немає майнових прав інтелектуальної власності, розпоряджання майновими правами щодо них неможливе.

Географічні зазначення зумовлені, зокрема, традиціями народу, природними чинниками, а саме кліматом, особливостями місцевості, іiі рослинністю тощо. Тому, хоча на географічні зазначення існують майнові права, договорів щодо розпоряджання майновими правами на цей об'єкт не укладають.

Відчуження комерційного найменування та комерційної таємниці можливе разом із цілісним майновим комплексом, але щодо цих об'єктів ліцензійні договори не укладають, оскільки вони невіддільні від суб'єкта господарювання. Комерційна таємниця $є$ режимом охорони конфіденційної інформації суб'єкта господарювання. Комерційна таємниця є широким поняттям, що не завжди може містити відомості суто про об'єкти права інтелектуальної власності. Проте складові частини комерційної таємниці, що є об'єктами права інтелектуальної власності суб'єкта господарювання, а саме технічні рішення, ноу-хау й інші, можна надавати у використання за ліцензійним договором, відчужувати майнові права на них.

Сторони договору. Не кожен суб'єкт права інтелектуальної власності може бути стороною договору щодо розпоряджання майновими правами інтелектуальної власності. Сторонами таких договорів можуть бути особи 3 повною цивільною дієздатністю, хоча у ст. 32 ЦК України встановлено, що особи 3 неповною цивільною дієздатністю мають право самостійно здійснювати права на свої об'єкти права інтелектуальної власності, отже, вони мають право укладати договори щодо розпоряджання своїми результатами інтелектуальної, творчої діяльності. Автором об'єкта права інтелектуальної власності може бути будь-яка фізична особа незалежно від віку та стану здоров'я, проте вступати в договірні відносини від імені та в інтересах частково дієздатних, обмежено дієздатних та недієздатних осіб можуть їхні законні представники батьки, усиновителі, піклувальники, опікуни. Зауважимо, що автором не може бути юридична особа, проте вона може бути стороною договору.

Строк договору. Строк договорів у сфері інтелектуальної власності визначається за погодженням сторін і залежить від виду договору й об'єкта права інтелектуальної власності, щодо якого він укладається. Ліцензійні договори укладаються на строк, який не може перевищувати терміну дії майнових прав на конкретний об'єкт права інтелектуальної власності. Договори про передання виключних майнових прав інтелектуальної власності є безстроковими, оскільки спрямовані на безповоротне відчуження виключних майнових прав інтелектуальної власності, якщо ж строк дії майнових прав на об'єкт права інтелектуальної власності завершився, будь-яка особа може безоплатно та без дозволу використовувати об'єкт 
права інтелектуальної власності. У договорах щодо створення об'єктів права інтелектуальної власності на замовлення сторони самостійно визначають строк виконання договору 3 урахування творчого характеру таких результатів.

Форма договору. Договори у сфері інтелектуальної власності укладаються в письмовій формі, хоча можливі винятки щодо договорів про опублікування творів у періодичних виданнях. Факт відчуження майнових прав, зокрема на винаходи, корисні моделі, зареєстровані промислові зразки, торговельні марки, компонування напівпровідникових виробів, підлягає державній реєстрації. Проте вважаємо необхідним реєстрацію факту відчуження також щодо об'єктів авторського права й інших об'єктів права інтелектуальної власності, щодо яких можливе укладання договорів. Хоча законодавством України не передбачається обов'язкової реєстрації факту надання дозволу на використання об'єктів права інтелектуальної власності, проте 3 метою уникнення зловживань, коли йдеться, зокрема, про виключну чи одиничну ліцензію, така реєстрація не видається зайвою.

Види договорів у сфері інтелектуальної власності. У законодавстві України $^{3}$ серед договорів щодо розпоряджання майновими правами інтелектуальної власності виділено ліцензію, ліцензійний договір, договір про передання виключних майнових прав інтелектуальної власності та договір про створення на замовлення і використання об'єкта права інтелектуальної власності. Крім того, до договорів у сфері інтелектуальної власності відносять також договір комерційної концесії, виділений у гл. 76 ЦК України, гл. 36 Господарського кодексу України від 16 січня 2003 р. (далі - ГК України), оскільки він спрямований на надання комплексу об'єктів права інтелектуальної власності у використання. Нами вже було зазначено вище необхідність об’єднання в одну главу ЦК України положень про договір комерційної концесії та договори щодо розпоряджання майновими правами інтелектуальної власності. Договори у сфері інтелектуальної власності $€$ консенсуальними (рідше - реальними), двосторонніми, відплатними (інколи безоплатними, якщо про це вказано в договорі).

Виділення ліцензії серед договорів у сфері інтелектуальної власності, зазначених у ст. 1107 ЦК України, є дискусійним. Ліцензія є дозволом. Ліцензія завжди $є$ складовою частиною ліцензійного договору. Також ліцензія може бути представлена окремим документом. Проте, на відміну від ліцензійного договору, ліцензія $\epsilon$ одностороннім правочином. Відповідно до ч. 1 ст. 626 ЦК України, договором є домовленість двох або більше сторін, спрямована на встановлення, зміну чи припинення цивільних

\footnotetext{
${ }^{3}$ Цивільний кодекс України : Закон України від 16 січня 2003 p. № 435-IV. URL: http://zakon.rada.gov.ua/ laws/show/435-15 (дата звернення: 25.11.2020).
} 
прав і обов'язків. Отже, якщо ліцензія представлена окремо від ліцензійного договору як окремий документ, це одностороннє волевиявлення особи, яке не зобов'язує інших осіб використовувати об'єкт права інтелектуальної власності. Існує поняття одностороннього договору, відповідно до ч. 2 ст. 626 ЦК України договір є одностороннім, якщо одна сторона має певні зобов'язання перед другою стороною, а друга сторона має тільки право вимоги, без виникнення зустрічного обов'язку, тоді як ліцензія - це надання особою, що має виключне право дозволяти використання об'єкта права інтелектуальної власності, письмового повноваження іншій особі, яке надає останній право на використання цього об'єкта в певній обмеженій сфері (ч. 1 ст. 1108 ЦК України). Тобто ліцензія $є$ одностороннім правочином, а не договором. Поняття правочину є ширшим за поняття договору. Це підтверджує положення ч. 2 ст. 11 ЦК України, де вказано, що підставами для виникнення цивільних прав і обов'язків $\epsilon$, зокрема, договори й інші правочини. Кожен договір $\epsilon$ правочином, але не кожний правочин $\epsilon$ договором. Правочином $є$ дія особи, спрямована на набуття, зміну чи припинення цивільних прав і обов'язків (ч. 1 ст. 202 ЦК України). Розрізняють односторонні, дво- та багатосторонні правочини, 3 них два останні правочини і $є$ договорами. Односторонній правочин не $є$ договором. Відповідно до ч. 3 ст. 202 ЦК України, одностороннім правочином є дія однієї сторони, що може бути представлена однією або кількома особами, крім того, односторонній правочин може створювати обов'язки тільки для особи, що його вчинила, а для інших осіб - тільки у випадках, установлених законом, або за домовленістю із цими особами ${ }^{4}$.

Крім цих договорів, особи мають право укласти інший договір, не передбачений цивільним законодавством, головне, щоби такий договір відповідав основним його засадам. Оскільки ці договори чітко закріплені у ЦК України, їх називають поіменованими. Надалі розглянемо договори у сфері інтелектуальної власності, виділені у ЦК України, та порівняємо їх із договірними конструкціями, закріпленими у спеціальному законодавстві України, у сфері інтелектуальної власності.

\section{2. Види поіменованих договорів у сфері інтелектуальної власності}

Ліцензійний договір. Аналіз чинного законодавства 3 інтелектуальної власності, що стосується питань надання дозволу на використання об'єктів права інтелектуальної власності, дозволяє зробити висновки про неузгодженість окремих його положень. Положення, які стосуються ліцензійного договору, висвітлені у ЦК України, а також у спеціальному

\footnotetext{
Цивільний кодекс України : Закон України від 16 січня 2003 p. № 435-IV. URL: http://zakon.rada.gov.ua/laws/show/435-15 (дата звернення: 25.11.2020).
} 
законодавстві у сфері інтелектуальної власності, а саме в законах України «Про охорону прав на винаходи і корисні моделі» від 15 грудня 1993 р., «Про охорону прав на промислові зразки» від 15 грудня 1993 р., «Про охорону прав на знаки для товарів і послуг» від 15 грудня 1993 р., «Про охорону прав на компонування напівпровідникових виробів» від 5 листопада 1997 р., «Про охорону прав на сорти рослин» від 21 квітня 1993 р. У Законі України «Про авторське право і суміжні права» від 23 грудня 1993 р. замість конструкції «ліцензійний договір» використано конструкцію «договір про передачу виключного/невиключного права на використання твору». На практиці це спричиняє труднощі 3 вибором договірної форми щодо надання дозволу на використання об'єктів авторського права.

Серед проблемних питань, що стосуються ліцензійного договору, спробуємо розкрити декілька.

Коло об’єктів права інтелектуальної власності, щуодо яких можливе укладення лічензійного договору. Вище нами було розглянуто види об'єктів права інтелектуальної власності, стосовно яких неможливе укладення договорів щодо розпоряджання майновими правами інтелектуальної власності або таке розпоряджання $є$ обмеженим. У літературі ${ }^{5}$ висвітлено позиції, що ліцензійний договір не може укладатись щодо об'єктів авторського права. У Законі України «Про авторське право і суміжні права», як уже зазначалося, немає згадки про ліцензійний договір, а дозвіл на використання об'єктів авторського права надається за договором про передачу права на використання твору. Проте ЦК України має вищу юридичну силу, ніж Закон України «Про авторське право і суміжні права», тому ліцензійний договір потрібно застосовувати 3 метою надання дозволу на використання об'єктів авторського права. До того ж назва договірної конструкції «договір про передачу права на використання твору» містить суперечливе поняття «передача права», яке може тлумачитись i як відчуження права. Ситуацію рятує використання в назві договору уточнення «на використання», проте, на наш погляд, не варто називати договори про відчуження майнового права та надання дозволу на використання об’єктів авторського права схожими поняттями, щоб не заплутувати на практиці суб'єктів договірних відносин та інших осіб, які матимуть справу з такими договорами.

\footnotetext{
5 Яворська О.С. Договори про передання майнових прав інтелектуальної власності. Сучасні актуальні проблеми права інтелектуальної власності у країнах Центрально-Східної Європи: теорія, методологія, практика : збірник наукових праць за матеріалами Всеукраїнського науково-методичного семінару, 28 червня 2015 р. Національна академія наук України ; Київський університет права ; Міжнародний центр правових та історико-політичних досліджень країн Центрально-Східної Європи. Львів : Галицька видавнича спілка, 2015. С. 16.
} 
Приналежність майнових прав інтелектуальної власності. Положення ст. 1109 ЦК України є досить суперечливими, бо в них ідеться про «надання дозволу на використання об'єкта права інтелектуальної власності» і про «надання права на використання об’єкта права інтелектуальної власності». Проте вважаємо, що за ліцензійним договором майнове право інтелектуальної власності залишається в ліцензіара, а ліцензіату лише надається дозвіл використовувати об'єкт права інтелектуальної власності без переходу йому майнових прав. Якщо за договором ліцензіар надає повноваження ліцензіату щодо укладення субліцензійного договору, це не означає передання майнових прав ліцензіату, надаються лише повноваження. Оскільки в ліцензіата за ліцензійним договором не виникає майнових прав, тому вони не можуть переходити його правонаступникам.

Територія як одна з істотних умов договору. На відміну від інших цивільно-правових договорів, серед істотних умов ліцензійного договору виділено територію. У ч. 7 ст. 1109 ЦК України закріплено, якщо в ліцензійному договорі не вказано інше, дія договору поширюється на територію України. Отже, допускається можливість зазначення в договорі території іншої держави. Проте потрібно враховувати вид об'єкта права інтелектуальної власності, стосовно якого укладається договір. Зокрема, реєстрація винаходів, корисних моделей має територіальний характер, тому в разі реєстрації таких об'єктів тільки в Україні вказувати в договорі іншу країну безпідставно. Інша ситуація з об'єктами авторського права, дія яких $є$ екстериторіальною.

У підсумку зазначимо, що в разі укладання ліцензійних договорів варто бути дуже обережними, розуміти правову природу та специфіку різних об'єктів права інтелектуальної власності. Положення загального та спеціального законодавства щодо розпоряджання майновими правами на об'єкти права інтелектуальної власності, зокрема й надання дозволу на використання об'єктів права інтелектуальної власності, є поверхневими та неузгодженими одне з одним. Усе це зумовлює потребу вивчення цієї проблеми та відповідного врегулювання.

Договір комерційної концесії. Такий договір закріплений у гл. 76 ЦК України та гл. 36 ГК України. За договором комерційної концесії надається дозвіл на використання комплексу об'єктів права інтелектуальної власності. Крім того, до предмета договору віднесено також комерційний досвід та ділову репутацію (ч. 1 ст. 1116 ЦК України, ч. 2 ст. 366 ГК України). Розглянемо особливості правовідносин за таким договором:

- договір укладається виключно між суб'єктами господарювання;

- правоволоділець надає дозвіл на використання комплексу своїх об'єктів права інтелектуальної власності (зокрема, торговельної марки, винаходів, 
промислових зразків, творів) з метою територіального розширення свого бізнесу, що має позитивний економічний ефект. У свою чергу, користувач, коли використовує об'єкти права інтелектуальної власності правоволодільця, користується його діловою репутацією;

- правоволоділець зобов'язується передати користувачу відповідні технічні документи, навчити його використовувати об'єкти права інтелектуальної власності, а також надавати постійні консультації, контролювати якість товарів та послуг користувача;

- користувач зобов'язується використовувати об'єкти права інтелектуальної власності, забезпечувати не гіршу за правоволодільця якість товарів і послуг, не розкривати конфіденційної інформації правоволодільця, а також дотримуватись його інструкцій.

У договорі можуть бути встановлені обов'язки правоволодільця не надавати іншим особам дозволу на використання цих самих об'єктів права інтелектуальної власності на територіях користувача, обов'язки користувача не укладати 3 конкурентами чи потенційними конкурентами правоволодільця договорів комерційної концесії щодо аналогічних товарів i послуг, погоджувати із правоволодільцем місцерозташування приміщень, їхнє зовнішнє і внутрішнє оформлення тощо.

Спірним видається виділення в ч. 1 ст. 1116 ЦК України, що предметом договору комерційної концесії можуть бути комерційна таємниця, комерційний досвід, ділова репутація, оскільки вважаємо їх невіддільними від правоволодільця. Проте поділяємо позицію, висвітлену в літературі, що ділова репутація надається автоматично з інтелектуальними досягненнями правовласника ${ }^{6}$.

Договір про передання виключних майнових прав інтелектуальної власності. Договір про передання виключних майнових прав інтелектуальної власності, наведений у гл. 75 ЦК України, спрямований на відчуження майнових прав інтелектуальної власності. Розглянемо ознаки такого договору, що його відрізняють від інших договорів у сфері інтелектуальної власності.

Предмет договору. За договором про передання виключних майнових прав інтелектуальної власності - майнові права інтелектуальної власності відчужуються безповоротно назавжди. Відчужуються саме майнові права інтелектуальної власності, а не річ. Однак, якщо назву такого договору сприймати окремо, не заглиблюватися в інші поіменовані договори, виділені у гл. 75 ЦК України, то незрозумілою є конструкція «передання виключного майнового права інтелектуальної власності». По-перше, як уже зазначалося

\footnotetext{
${ }^{6}$ Коваль І.Ф. Комерціалізація прав інтелектуальної власності : навчальний посібник. Київ : ЮрінкомІнтер, 2018. С. 86.
} 
вище, «передання права» може тлумачитись і як надання у використання, $\mathrm{i}$ як відчуження майнового права. Це доводить аналіз спеціального законодавства у сфері інтелектуальної власності, зокрема Закону України «Про авторське право і суміжні права», де вжито конструкцію «передача права на використання». Тому, на наш погляд, щоб не плутати абсолютно різні поняття «відчуження майнового права інтелектуальної власності» та «надання дозволу на використання об’єкта права інтелектуальної власності», варто замінити у ЦК України поняття «передання виключного майнового права інтелектуальної власності» на «відчуження майнового права інтелектуальної власності». Також відповідні зміни треба внести до спеціального законодавства у сфері інтелектуальної власності. По-друге, у ст. 1113 ЦК України вказується, що передаються саме виключні майнові права інтелектуальної власності. Незрозуміло, які саме права законодавець відносить до виключних майнових прав інтелектуальної власності. 3 одного боку, законодавець оперує поняттями «виключні/невиключні права», навіть в інших договірних конструкціях, зокрема щодо надання дозволу на використання ${ }^{7}$. Наприклад, у ч. 2 ст. 32 Закону України «Про авторське право і суміжні права» ідеться про передачу виключного і невиключного права на використання твору. Проте в законодавстві не знаходимо чіткої позиції щодо переліку цих прав чи їх тлумачення. У загальному та спеціальному законодавстві у сфері інтелектуальної власності спостерігаємо неоднозначні положення щодо віднесення майнових прав інтелектуальної власності до виключних чи невиключних. Щодо об'єктів авторського права та суміжних прав спостерігаємо відмінність у положеннях ст. ст. 440, 452 ЦК України зі ст. 424 ЦК України щодо виключності/невиключності права перешкоджання неправомірному використанню i заборони такого використання об'єктів авторського права та суміжних прав. На перший погляд видається, що це специфіка об’єктів авторського права та суміжних прав, проте інше бачимо у ст. ст. 15, 39-41 Закону України «Про авторське право і суміжні права». Крім того, у ст. ст. 440, 452 ЦК України «право на використання» не вказане як виключне, а у ст. ст. 15, 40-41 Закону України «Про авторське право і суміжні права» зазначено протилежне. Така ж ситуація у відмінностях положень загального та спеціального законодавства щодо виключності/невиключності права на використання промислових зразків, відображених у ст. 464 ЦК України та в ч. 2 ст. 20 Закону України «Про охорону прав на промислові зразки». Можливо, виходячи з положень ч. ч. 3-4 ст. 32 Закону України «Про авторське право і суміжні права», законодавець під «виключними майновими правами», які відчужуються за

\footnotetext{
7 Про авторське право і суміжні права : Закон України від 23 грудня 1993 р. № 3792-XII. URL: https://zakon.rada.gov.ua/laws/show/3792-12 (дата звернення: 25.11.2020).
} 
договором, мав на увазі, що правоволоділець, коли передає свої майнові права інтелектуальної власності набувачу, зобов'язується більше їх не використовувати (як у разі виключної ліцензії). Проте це й так очевидно, оскільки йдеться не про ліцензійний договір, а про договір щодо відчуження майнових прав. У зв'язку із цим уважаємо зайвим уточнення в назві договору, що відчужуються саме виключні майнові права.

Згадка про договір щодо передачі (відчуження) майнових прав інтелектуальної власності наявна також у законах України «Про авторське право і суміжні права» та «Про охорону прав на сорти рослин». В іншому спеціальному законодавстві у сфері інтелектуальної власності ${ }^{8}$ вживається конструкція «договір про передачу права власності», що суперечить не тільки ЦК України, але й сутності договорів щодо розпоряджання майновими правами інтелектуальної власності. Хоча варто зауважити, що, відповідно до останніх змін законодавства у сфері інтелектуальної власності, у законах України «Про охорону прав на винаходи і корисні моделі», «Про охорону прав на знаки для товарів і послуг» було замінено конструкцію «передання права власності» на «передання виключних майнових прав інтелектуальної власності», а в Законі України «Про охорону прав на промислові зразки» замінено на «передання майнових прав інтелектуальної власності», проте згадка про «договір про передачу права власності» у цих законах залишилась. Об'єкти права інтелектуальної власності не є об'єктами речового права. Передають право власності на річ за договором купівлі-продажу, який не можна застосовувати 3 метою розпоряджання майновими правами інтелектуальної власності. Необхідно розмежовувати річ і майнові права інтелектуальної власності. Зокрема, особа, яка створила новий промислово придатний спосіб приготування торта, який відповідає критеріям правової охорони корисної моделі, не набуває права на торт як на річ, поки його не приготує, у неї виникає право інтелектуальної власності на цей результат на підставі державної реєстрації. Особа може дозволити іншим використовувати спосіб приготування торта за ліцензійним договором або відчужити майнове право інтелектуальної власності на користь інших осіб. Проте, коли купуємо торт як річ, ми не набуваємо на нього прав інтелектуальної власності. Варто наголосити, що під «використанням об'єкта права

\footnotetext{
8 Про охорону прав на промислові зразки : Закон України від 15 грудня 1993 р. № 3688-XII. URL: http://zakon.rada.gov.ua/laws/show/3688-12 (дата звернення: 25.11.2020) ; Про охорону прав на винаходи і корисні моделі : Закон України від 15 грудня 1993 p. № 3687-XII. URL: http://zakon3.rada.gov.ua/ laws/show/3687-12 (дата звернення: 25.11.2020) ; Про охорону прав на знаки для товарів і послуг : Закон України від 15 грудня 1993 р. № 3689-XII. URL: http://zakon.rada.gov.ua/laws/show/3689-12 (дата звернення: 25.11.2020); Про охорону прав на компонування напівпровідникових виробів : Закон України від 5 листопада 1997 p. № 621/97-BP. URL: http://zakon.rada.gov.ua/laws/show/621/97-\%D0\%B2\%D1\%80 (дата звернення: 25.11.2020).
} 
інтелектуальної власності» розуміють використання майнових прав інтелектуальної власності, а не об'єкта як речі.

Обсяг майнових прав інтелектуальної власності, щзо відчужуються. Майнові права інтелектуальної власності можуть відчужуватись як повністю, так і частково (ч. 1 ст. 1113 ЦК України). Проте варто брати до уваги особливості розпоряджання майновими правами на окремі об'єкти права інтелектуальної власності. Якщо майнові права на об'єкти авторського права можна відчужити частково або цілком, майнові права на торговельні марки або цілком, або щодо частини товарів і послуг, вказаних у свідоцтві, то щодо об'єктів патентного права (винаходи і корисні моделі) дроблення права неможливе. Крім того, реєстрація майнових прав на об'єкти патентного права має територіальний характер. Тому набувач має розуміти, якщо, зокрема, на винахід $є$ тільки патент України, то майнові права інтелектуальної власності не діють щодо цього результату в інших країнах.

Строк договору. Договір про передання виключних майнових прав інтелектуальної власності $є$ безстроковим. Незважаючи на те, що права інтелектуальної власності за таким договором відчужуються назавжди, проте варто пам'ятати, якщо строк дії майнових прав інтелектуальної власності завершився, то такі права переходять у суспільне надбання, а отже, набувач уже не матиме права забороняти їх використання іншим особам.

Особливі права ц̌ обов'язки сторін за договором. Правоволоділець майнових прав інтелектуальної власності зобов'язаний повідомити набувача таких прав про ліцензійні договори, укладені правоволодільцем з іншими особами щодо об'єктів права інтелектуальної власності, які передаються набувачу. Зокрема, якщо на час укладення договору про відчуження майнових прав інтелектуальної власності правоволоділець уклав раніше ліцензійний договір, за яким надано виключну ліцензію, набувач зобов'язується не використовувати майнові права інтелектуальної власності та не надавати іншим особам дозвіл на використання об'єкта права інтелектуальної власності на час дії такого ліцензійного договору.

Якщо йдеться про відчуження майнового права на винаходи, корисні моделі, ноу-хау, то особа, яка передає майнові права інтелектуальної власності, зобов'язана навчити набувача прав використовувати такий результат, передати йому відповідну технічну документацію. Інакше особа, яка набула майнових прав інтелектуальної власності, не зможе використовувати результат. Обидві сторони мають дотримуватись умов конфіденційності, зокрема не розголошувати суть технічного результату, ноу-хау. Набувач майнових прав інтелектуальної власності зобов'язаний дотримуватись особистих немайнових прав автора, зокрема вказувати його ім’я в разі використання об'єкта права інтелектуальної власності. 
Набувач має знати про необхідність сплати зборів за підтримку чинності майнових прав інтелектуальної власності на об'єкти, для яких це передбачено в чинному законодавстві, бо в разі не продовження дії таких прав майнові права втрачають чинність.

Отже, у разі укладання договору щодо передання виключних майнових прав інтелектуальної власності необхідно враховувати ключові ознаки такого договору, наведені вище, а також пам'ятати, що такі права відчужуються назавжди, а не надаються у використання. Тому пропонуємо замінити назву договору, викладену у ЦК України, на «договір про відчуження майнових прав інтелектуальної власності», а також внести відповідні зміни до спеціального законодавства у сфері інтелектуальної власності. Уважаємо за необхідне виключити з назви договірної конструкції вказівку, що передаються виключні права, оскільки такий договір спрямований на відчуження майнових прав інтелектуальної власності, тому уточнення про «виключність» прав не має смислового навантаження.

Договір про створення на замовлення і використання об'єкта права інтелектуальної власності. Назва договірної конструкції, що закріплена у ЦК України, щодо створення об'єктів інтелектуальної, творчої діяльності на замовлення - «договір про створення за замовленням і використання об'єкта права інтелектуальної власності» - викликає низку запитань щодо мети такого договору й актуальності щодо практичного використання. Як бачимо з назви, за таким договором створений об’єкт права інтелектуальної власності надається замовникові у використання, хоча логічним видається очікування замовника на відчуження йому майнових прав інтелектуальної власності на такий результат. Серед істотних умов такого договору, відповідно до ч. 2 ст. 1112 ЦК України, виділено способи й умови використання об'єкта права інтелектуальної власності. Проте вважаємо це положення дискусійним, бо якщо об'єкт створюється на замовлення, подальше розпоряджання майновими правами інтелектуальної власності на створений результат має здійснюватися замовником. Сторонами такого договору є замовник та майбутній автор. Такий договір не укладається між юридичними особами, оскільки останні не можуть створювати результатів інтелектуальної, творчої діяльності. Також дискусійним питанням є визначення кола об'єктів права інтелектуальної власності, щодо яких можливе укладання договору замовлення.

Спробуємо зупинитися детальніше на ключових особливостях договору про створення на замовлення і використання об'єкта права інтелектуальної власності.

Одна зі сторін договору - обов'язково фізична особа. Це зумовлено природою самого договору. Юридична особа не створює результатів інтелектуальної, творчої діяльності, автором може бути тільки людина. 
Майбутній автор зобов'язується створити об'єкт особисто. Поділяємо позиції, висвітлені в літературі ${ }^{9}$, про умовність зазначення в договорі однієї зі сторін автором, доки об'єкта не існує. Справді, фактично це майбутній автор, а на момент укладення договору фізична особа ще не $є$ автором, вона лише погоджується створити об'єкт права інтелектуальної власності в майбутньому. На практиці часто трапляється, що юридична особа замовляє створення об'єкта права інтелектуальної власності в іншої юридичної особи. Зрозуміло, що створювати об’єкт в будь-якому разі буде фізична особа, яка, зокрема, або працює на юридичну особу, або має відповідні зобов'язання за договором, або подарувала свій результат тощо. Науковцями ${ }^{10}$ порушуються питання щодо договірної конструкції, яку треба застосовувати тоді, коли договір про створення об'єкта права інтелектуальної власності на замовлення укладається між юридичними особами. Поширені позиції ${ }^{11}$, відповідно до яких наявний інший договір, якщо правовідносини стосовно створення об’єкта права інтелектуальної власності виникають між юридичними особами, не договір про створення на замовлення і використання об'єкта права інтелектуальної власності, передбачений у ЦК України. Справді, у положенні ч. 1 ст. 1112 ЦК України чітко визначено, що стороною договору $\epsilon$ творець, зокрема письменник, художник. Із цим важко погодитись, оскільки вважаємо, що в положеннях такого договору між юридичними особами необхідно вказати умови про зобов'язання юридичної особи, що відповідає за створення об'єкта права інтелектуальної власності, укласти відповідний договір про створення результату з майбутнім автором. Автор, у свою чергу, зобов'язується створити об'єкт права інтелектуальної власності, відчужити свої майнові права на такий результат юридичній особі.

Відсутність об'єкта права інтелектуальної власності на момент укладення договору. Ця особливість договору закладена в його назві, що одразу дозволяє зрозуміти спрямування договору. Оскільки об'єкт права інтелектуальної власності буде створено в майбутньому на замовлення, то замовник висуває свої вимоги до такого результату. Також замовник має враховувати ризики, пов'язані з особливостями творчої діяльності, адже не завжди автор зможе створити саме те, на що очікує замовник, тому що творча діяльність не $\epsilon$ шаблонною, вона виражає власне бачення автора, що може не збігатися з уявленнями замовника про об'єкт права інтелектуальної власності.

\footnotetext{
9 Бажанов В.О. Договір про створення за замовленням і використання об'єкта авторського права в цивільному праві України. Право і суспільство. 2014. № 6-1. С. 64.

10 Жилінкова О.В. Договірне регулювання відносин щодо інтелектуальної власності в Україні та за кордоном : монографія. Київ : Юрінком-Інтер, 2015. С. 119-120 ; Якубівський І.Є. Набуття, здійснення та захист майнових прав інтелектуальної власності в Україні : монографія. Львів : ЛНУ імені Івана Франка, 2018. С. 382-383.

11 Якубівський I.С. Набуття, здійснення та захист майнових прав інтелектуальної власності в Україні : монографія. Львів : ЛНУ імені Івана Франка, 2018. С. 383.
} 
Об 'єкти права інтелектуальної власності, щодо яких можливе укладення договору. Вище нами було розглянуто питання щодо об'єктів права інтелектуальної власності, стосовно яких не укладають договори щодо розпоряджання майновими правами інтелектуальної власності. Що стосується договору про створення об’єкта права інтелектуальної власності на замовлення, то варто враховувати специфіку виникнення майнових прав інтелектуальної власності на різні об'єкти творчої, інтелектуальної діяльності. На одні об'єкти права інтелектуальної власності діє принцип автоматичної правової охорони, на інші - реєстраційна система виникнення майнових прав інтелектуальної власності. Коли йдеться про об'єкти 3 реєстраційною системою виникнення майнових прав інтелектуальної власності, то спірною є можливість їх створення на замовлення.

Крім ЦК України, згадка про договір замовлення щодо створення об'єктів права інтелектуальної власності наявна в законах України «Про авторське право і суміжні права», «Про охорону прав на сорти рослин». У літературі ${ }^{12}$ зазначено, що на практиці договір про створення на замовлення $\mathrm{i}$ використання об'єкта права інтелектуальної власності зазвичай спрямований на створення об'єктів авторського права. Відомо, що авторське право на результати інтелектуальної, творчої діяльності виникає автоматично з моменту їх створення. Саме тому на об'єкти авторського права відсутній охоронний документ, а свідоцтво про реєстрацію авторського права на твір лише засвідчує факт їх реєстрації. Отже, можливе створення об'єктів авторського права на замовлення. Слушними вважаємо думки, висвітлені в літературі ${ }^{13}$, що винаходи, корисні моделі, компонування напівпровідникових виробів, сорти рослин не можна створити на замовлення. Справді, ці об'єкти мають відповідати критеріям правової охорони, тому майнові права на них виникають на підставі державної реєстрації. Проте за договором автор може мати зобов'язання щодо отримання охоронного документа на створений ним результат, якщо правова охорона такого результату не виникає автоматично. Незважаючи на те, що сорт рослин має відповідати умовам правової охорони, у Законі України «Про охорону прав на сорти рослин» наявні положення про створення сорту на замовлення ${ }^{14}$.

У зв'язку 3 останніми змінами до законодавства України у сфері інтелектуальної власності в Україні, як і у країнах Європейського Союзу,

\footnotetext{
12 Жилінкова О.В. Договірне регулювання відносин щодо інтелектуальної власності в Україні та за кордоном : монографія. Київ : Юрінком-Інтер, 2015. С. 115.

13 Якубівський І.С. Набуття, здійснення та захист майнових прав інтелектуальної власності в Україні : монографія. Львів : ЛНУ імені Івана Франка, 2018. С. 373.

14 Про охорону прав на сорти рослин : Закон України від 21 квітня 1993 р. № 3116-XII. URL: https://zakon.rada.gov.ua/laws/show/3116-12 (дата звернення: 25.11.2020).
} 
охороняються промислові зразки, як зареєстровані, так і незареєстровані ${ }^{15}$. Тому вважаємо логічним, що промислові зразки можна створити за договором замовлення. Об'єкти суміжних прав теж можна створити за договором замовлення, єдине, оскільки суміжні права тісно пов'язані 3 авторськими, щоб створення такого об'єкта було правомірним, потрібний дозвіл автора на використання його твору. Майнові права на торговельну марку чинні від дати подачі заявки. Проте торговельна марка може охоронятися також без реєстрації, зокрема, якщо вона визнана добре відомою. Оскільки в разі створення позначення невідомо, чи буде воно торговельною маркою, тому спірною вважаємо можливість створення торговельної марки на замовлення. Комерційну таємницю і ноу-хау можна створити за договором замовлення, проте необхідно одразу 3 моменту їх створення вжити заходів щодо збереження результату в конфіденційності, зобов'язати їхнього автора не розголошувати таку інформацію. Отже, уважаємо, якщо для виникнення об'єкта права інтелектуальної власності недостатнім $є$ факт його створення, автор за договором зобов'язується набути прав інтелектуальної власності на створений ним результат.

Майнові права інтелектуальної власності та їх розподіл за договором. За загальним положенням ч. 2 ст. 430 ЦК України, майнові права інтелектуальної власності на об’єкт, створений на замовлення, належать спільно його автору і замовнику, якщо інше не вказано в договорі. Проте в ч. 3 ст. 1112 ЦК України наведено виняток із цього положення щодо творів образотворчого мистецтва, майнові права інтелектуальної власності на які належать автору, якщо інше не передбачено договором. Таке положення, на наш погляд, суперечить призначенню договору. Якщо особа замовляє створення для неї певного об'єкта права інтелектуальної власності, то майнові права мають за договором переходити замовнику, якщо інше не буде вказано в договорі. Про необхідність розподілу сторонами майнових прав інтелектуальної власності на створені результати інтелектуальної, творчої діяльності вказується в літературі ${ }^{16}$.

Ще одним дискусійним моментом видається сама назва договірної конструкції, закріплена у ЦК України, - «договір про створення за замовленням і використання об'єкта права інтелектуальної власності». Насамперед не зовсім логічним $є$ додавання до назви договору «використання об'єкта права інтелектуальної власності», оскільки в разі

\footnotetext{
15 Про охорону прав на промислові зразки : Закон України від 15 грудня 1993 р. № 3688-XII. URL: http://zakon.rada.gov.ua/laws/show/3688-12 (дата звернення: 25.11.2020).

16 Договірні форми розпоряджання майновими правами на об’єкти авторського права : монографія / кол. авт. ; за наук. ред. Н.М. Мироненко ; НДІ ІВ НАПрН України. Київ : Інтерсервіс, 2014. С. 35 ; Кодинець А.О. Цивільно-правове регулювання зобов'язальних інформаційних відносин: методологія, теорія, практика : дис. ... докт. юрид. наук: 12.00.03. Київ, 2016. С. 251.
} 
створення об'єкта права інтелектуальної власності на замовлення очевидно, що замовник сам має визначати для себе способи використання такого об'єкта, а не його автор. На наш погляд, автор за договором зобов'язується створити об'єкт і передати (відчужити) майнові права інтелектуальної власності замовнику (разом із річчю, у яку втілений результат, якщо річ існує та неможливо відділити майнові права інтелектуальної власності від речі, у яку вони втілені). А за позицією законодавця замовнику переходить лише річ, і якщо про це в договорі не вказано, то автоматично автор має подальше право на використання та розпоряджання своїм результатом. У цивільному праві виділено окремо договори купівлі-продажу, проте договір про створення об'єктів права інтелектуальної власності на замовлення належить до групи договорів щодо розпоряджання майновими правами інтелектуальної власності, а не речами. Саме тому вважаємо, що такий договір може породжувати незрозумілі для замовника ситуації, коли річ перейшла в його власність, проте розпоряджатися нею не можна без дозволу автора. У зв'язку із цим потребують уточнення положення чинного законодавства щодо договору про створення об'єктів права інтелектуальної власності на замовлення, а саме необхідно вказати, що майнові права інтелектуальної власності належать замовнику, якщо інше не передбачено договором. Також уважаємо необхідним уточнити назву договору, прибрати вказівку, що стосується використання об'єкта права інтелектуальної власності, тобто викласти назву так: «договір про створення об'єкта права інтелектуальної власності на замовлення». Оскільки на практиці досить часто укладаються договори замовлення щодо створення об’єктів права інтелектуальної власності між юридичними особами, пропонуємо такі правовідносини закріпити у ЦК України, проте з обов'язковим уточненням, що майбутнім автором може бути тільки фізична особа, тому юридична особа, яка зобов'язалась відповідати за створення об'єктів права інтелектуальної власності, має укласти договір із майбутнім автором про створення об'єкта права інтелектуальної власності та набути від автора майнових прав інтелектуальної власності на цей результат. Крім того, пропонуємо не обмежувати коло об'єктів права інтелектуальної власності, які можна створити за договором замовлення. У такому разі доцільно вказати в договорі умови, за якими особа, яка зобов'язалась відповідати за створення об'єкта права інтелектуальної власності, або автор результату має набути права інтелектуальної власності на створений об'єкт, якщо такий результат не охороняється автоматично з моменту створення, та чи взагалі його можливо створити на замовлення. 


\section{ВИСНОВКИ}

За результатами дослідження особливостей договорів у сфері інтелектуальної власності за законодавством України пропонуємо:

1. Змінити назву гл. 75 ЦК України «Розпоряджання майновими правами інтелектуальної власності» на «Договори у сфері інтелектуальної власності», додати до цієї глави положення, що стосуються договору комерційної концесії. Позицію обгрунтовуємо тим, що «розпоряджання майновими правами інтелектуальної власності» $\epsilon$ широким поняттям, яке включає договірне i недоговірне розпоряджання. Положення гл. 75 ЦК України спрямовані тільки на договірне розпоряджання майновими правами інтелектуальної власності, тому назву цієї глави потрібно уточнити. Крім того, поняття «розпоряджання майновими правами інтелектуальної власності» застосовують до вже створених результатів інтелектуальної, творчої діяльності, які існують на момент укладення договору, тоді як у гл. 75 ЦК України $є$ положення щодо договору про створення на замовлення і використання об'єкта права інтелектуальної власності. Також пропонуємо у ЦК України до договорів у сфері інтелектуальної власності додати положення про договір комерційної концесії, оскільки цей договір також спрямований на розпоряджання майновими правами інтелектуальної власності.

2. Вилучити зі ст. 1107 ЦК України положення про те, що ліцензія на використання об'єкта права інтелектуальної власності є договором, оскільки ліцензія є одностороннім правочином, хоча, крім самостійного значення, ліцензія завжди є складовою частиною ліцензійного договору.

3. Узгодити із ЦК України положення Закону України «Про авторське право і суміжні права» щодо договірної конструкції, спрямованої на надання дозволу на використання відповідних об'єктів права інтелектуальної власності, а саме конструкцію «договір про передачу прав на використання» замінити на «ліцензійний договір».

4. Узгодити із ЦК України положення спеціального законодавства України усфері інтелектуальної власності щодо назв договірних конструкцій, спрямованих на відчуження майнових прав інтелектуальної власності. Також замінити назву договору про передання виключних майнових прав інтелектуальної власності, закріплену у ЦК України, на «договір про відчуження майнових прав інтелектуальної власності». Це обгрунтовуємо нечіткістю поняття «передання права», що може тлумачитись як надання дозволу на використання i як відчуження майнового права. Уважаємо необхідним виключити з назви договірної конструкції вказівку, що передаються виключні права, оскільки такий договір спрямований на відчуження майнових прав інтелектуальної власності, тому уточнення про «виключність» прав не має смислового навантаження. Крім того, відповідні зміни необхідно внести 
до спеціального законодавства у сфері інтелектуальної власності, а саме в законах України «Про охорону прав на винаходи і корисні моделі», «Про охорону прав на промислові зразки», «Про охорону прав на знаки для товарів і послуг», «Про охорону прав на компонування напівпровідникових виробів» замінити конструкцію «договір про передачу права власності» на «договір про відчуження майнових прав інтелектуальної власності», оскільки об'єкти права інтелектуальної власності не є об'єктами права власності.

5. Замінити назву договору про створення на замовлення і використання об'єкта права інтелектуальної власності, зазначену у ЦК України, на «договір про створення об'єкта права інтелектуальної власності на замовлення», оскільки вважаємо, що саме замовник має самостійно визначати способи використання новоствореного об'єкта права інтелектуальної власності. Крім того, це дозволить такий договір використовувати як універсальну конструкцію щодо створення об'єктів права інтелектуальної власності на замовлення. Майнові права інтелектуальної власності за договором замовлення пропонуємо закріпити за замовником, якщо інше не буде зазначено в договорі.

6. Урегулювати правовідносини, які виникають між юридичними особами, щодо створення об'єктів права інтелектуальної власності на замовлення шляхом внесення до ст. 1112 ЦК України уточнення, що майбутнім автором може бути тільки фізична особа, тому юридична особа, яка зобов'язалась відповідати за створення об'єкта права інтелектуальної власності, має укласти відповідний договір із майбутнім автором про створення об'єкта права інтелектуальної власності та набути в подальшому від автора майнових прав інтелектуальної власності на цей результат.

7. Розширити коло об'єктів права інтелектуальної власності, які можна створити за договором замовлення, шляхом унесення до ст. 1112 ЦК України положення, що особа, яка зобов'язалась за договором відповідати за створення об'єкта права інтелектуальної власності, або автор результату має набути права інтелектуальної власності на цей об'єкт, якщо на результат не діє принцип автоматичної правової охорони з моменту створення та його можливо створити на замовлення.

\section{АНОТАЦІЯ}

У дослідженні розглянуто особливості договорів щодо розпоряджання майновими правами інтелектуальної власності за законодавством України. Описано коло об'єктів права інтелектуальної власності, щодо яких можливе укладання таких договорів. Виділено ключові ознаки ліцензійного договору, договору комерційної концесії, договору про передання виключних майнових прав інтелектуальної власності, договору про створення на 
замовлення і використання об'єкта права інтелектуальної власності. Розглянуто недоліки законодавчого регулювання щодо розпоряджання майновими правами інтелектуальної власності, наведено шляхи їх усунення. 3'ясовано невідповідність спеціального законодавства України у сфері інтелектуальної власності положенням Цивільного кодексу України щодо договірного розпоряджання майновими правами інтелектуальної власності. Договори щодо розпоряджання майновими правами інтелектуальної власності спрямовані на розпоряджання саме майновими правами інтелектуальної власності, а не речами, тому використання у спеціальному законодавстві України договірної конструкції «договір про передачу права власності» не відповідає не тільки положенням Цивільного кодексу України, але і правовій природі об'єктів права інтелектуальної власності. Запропоновані зміни до Цивільного кодексу України та спеціального законодавства України у сфері інтелектуальної власності щодо договірного регулювання правовідносин інтелектуальної власності.

\section{ЛІТЕРАТУРА}

1. Бажанов В.О. Договір про створення за замовленням і використання об'єкта авторського права в цивільному праві України. Право і суспільство. 2014. № 6-1. С. 62-67.

2. Господарський кодекс України : Закон України від 16 січня 2003 р. № 436-IV. URL: https://zakon.rada.gov.ua/laws/show/436-15 (дата звернення: 25.11.2020).

3. Дмитришин В.С. Розпоряджання майновими правами інтелектуальної власності в Україні : навчальний посібник. Київ : Інститут інтелектуальної власності і права, 2008. 248 с.

4. Договірні форми розпоряджання майновими правами на об'єкти авторського права : монографія / кол. автор. ; за наук. ред. Н.М. Мироненко ; НДІ ІВ НАПрН України. Київ : Інтерсервіс, 2014. 248 с.

5. Жилінкова О.В. Договірне регулювання відносин щодо інтелектуальної власності в Україні та за кордоном : монографія. Київ : Юрінком-Інтер, 2015. $280 \mathrm{c}$.

6. Коваль І.Ф. Комерціалізація прав інтелектуальної власності : навчальний посібник. Київ : Юрінком-Інтер, 2018. 272 с.

7. Кодинець А.О. Цивільно-правове регулювання зобов'язальних інформаційних відносин: методологія, теорія, практика : дис. ... докт. юрид. наук: 12.00.03. Київ, 2016. 470 с.

8. Про авторське право і суміжні права : Закон України від 23 грудня 1993 р. № 3792-XII. URL: https://zakon.rada.gov.ua/laws/show/3792-12 (дата звернення: 25.112020.). 
9. Про охорону прав на винаходи і корисні моделі : Закон України від 15 грудня 1993 p. № 3687-XII. URL: http://zakon3.rada.gov.ua/laws/show/ 3687-12 (дата звернення: 25.11.2020).

10. Про охорону прав на знаки для товарів і послуг : Закон України від 15 грудня 1993 p. № 3689-XII. URL: http://zakon.rada.gov.ua/laws/show/ 3689-12 (дата звернення: 25.112020).

11. Про охорону прав на компонування напівпровідникових виробів : Закон України від 5 листопада 1997 p. № 621/97-BP. URL: http://zakon.rada.gov.ua/laws/show/621/97-\%D0\%B2\%D1\%80 (дата звернення: 25.11.2020).

12. Про охорону прав на промислові зразки : Закон України від 15 грудня 1993 p. № 3688-XII. URL: http://zakon.rada.gov.ua/laws/show/3688-12 (дата звернення: 25.11.2020).

13. Про охорону прав на сорти рослин : Закон України від 21 квітня 1993 p. № 3116-XII. URL: https://zakon.rada.gov.ua/laws/show/3116-12 (дата звернення: 25.11.2020).

14. Цивільний кодекс України : Закон України від 16 січня 2003 р. № 435-IV. URL: http://zakon.rada.gov.ua/laws/show/435-15 (дата звернення: 25.11.2020).

15. Яворська О.С. Договори про передання майнових прав інтелектуальної власності. Сучасні актуальні проблеми права інтелектуальної власності украӥнах Центрально-Східної Європи: теорія, методологія, практика : збірник наукових праць за матеріалами Всеукраїнського науково-методичного семінару, 28 червня 2015 р. Національна академія наук України ; Київський університет права ; Міжнародний центр правових та історико-політичних досліджень країн Центрально-Східної Європи. Львів : Галицька видавнича спілка, 2015. С. 14-17.

16. Якубівський I.Є. Набуття, здійснення та захист майнових прав інтелектуальної власності в Україні : монографія. Львів : ЛНУ імені Івана Франка, 2018. 522 с.

\section{Information about author:} Dmytrenko V. V.,

Candidate of Science of Law, Senior Lecturer at the Department of Information and Intellectual Property Law National Technical University of Ukraine "Igor Sikorsky Kyiv Polytechnic Institute" 37, Peremohy avenue, Kyiv, 02000, Ukraine 